\title{
Volcanogenic Massive Sulfide Deposit Density
}

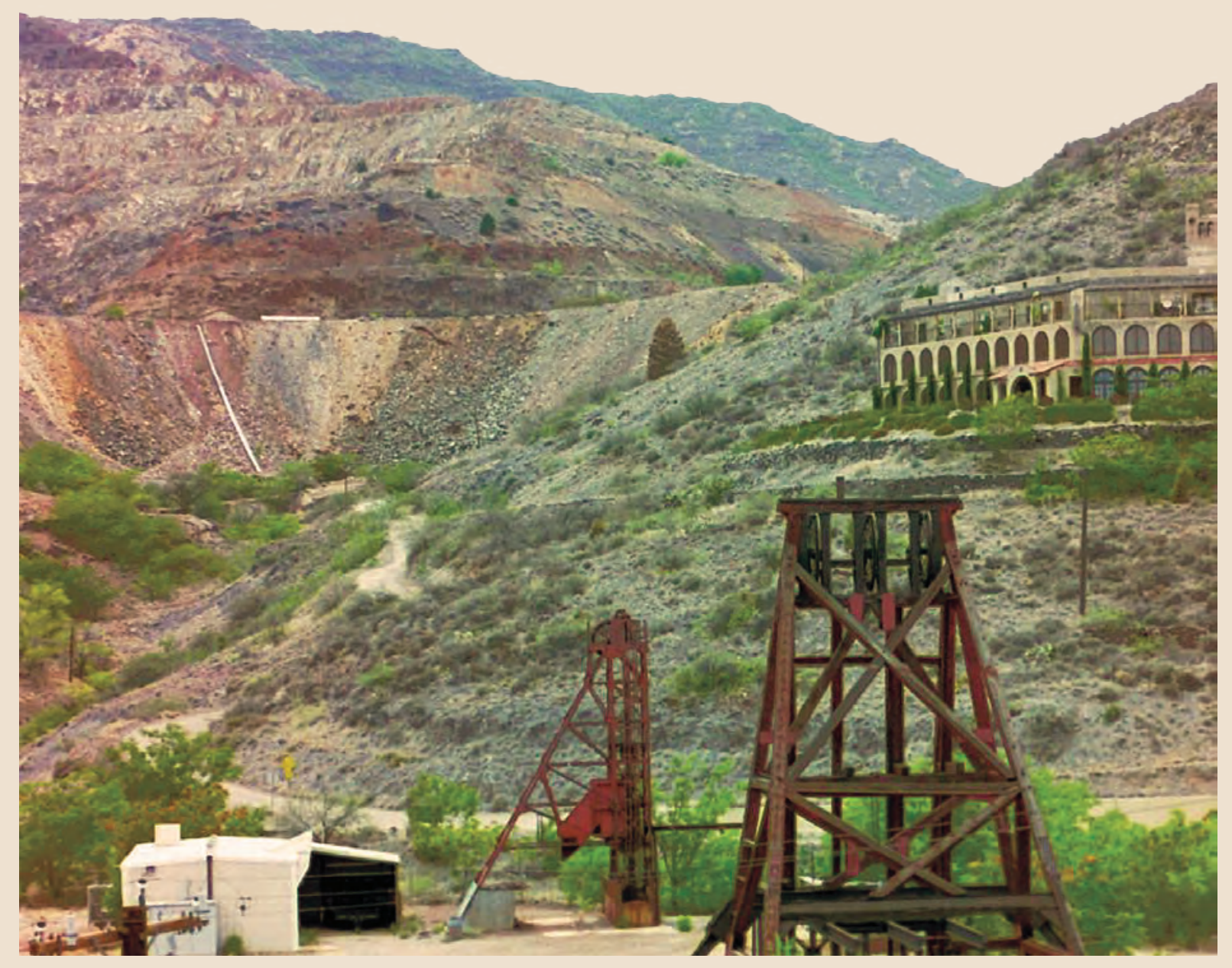

Scientific Investigations Report 2007-5082 



\section{Volcanogenic Massive Sulfide Deposit Density}

By Dan L. Mosier, Donald A. Singer, and Vladimir I. Berger

Scientific Investigations Report 2007-5082

U.S. Department of the Interior

U.S. Geological Survey 


\title{
U.S. Department of the Interior DIRK KEMPTHORNE, Secretary
}

\author{
U.S. Geological Survey \\ Mark D. Myers, Director
}

\section{U.S. Geological Survey, Reston, Virginia: 2007}

\author{
This report and any updates to it are available at: \\ http://pubs.usgs.gov/sir/2007/5082 \\ For product and ordering information: \\ World Wide Web: http://www.usgs.gov/pubprod \\ Telephone: 1-888-ASK-USGS \\ For more information on the USGS - the Federal source for science about the Earth, its natural and living \\ resources, natural hazards, and the environment: \\ World Wide Web: http://www.usgs.gov \\ Telephone: 1-888-ASK-USGS
}

Manuscript approved for publication, May 3, 2007

Text edited by Tracey Suzuki

Layout by David R. Jones

Any use of trade, product, or firm names is for descriptive purposes only and does not imply endorsement by the U.S. Government.

Although this report is in the public domain, permission must be secured from the individual copyright owners to reproduce any copyrighted materials contained within this report.

Cataloging-in-publication data are on file with the Library of Congress (http://www.loc.gov/).

Cover-View of the United Verde mine (upper left), the Edith and Audrey shafts of the United Verde Extension mine (foreground), and the abandoned Little Daisy Hotel, which was a dormitory for the miners (upper right), Jerome, Arizona. (U.S. Geological Survey photograph taken by Dan Mosier in 2002) 


\section{Contents}

Abstract
Introduction
Methodology
Delineation of Control Areas
Volcanogenic Massive Sulfide Deposit Densities
Erosion and Densities
Area and Densities
Summary and Conclusions
References Cited

\section{Figures}

1. Histogram of volcanogenic massive sulfide deposit densities per 100,000 square kilometers ...10

2. Relationship of map scale and volcanogenic massive sulfide deposits

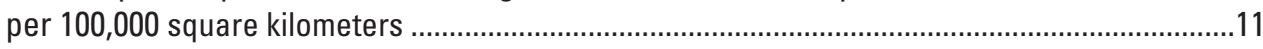

3. Volcanogenic massive sulfide deposits control area exposed versus density of deposits ...................................................................................................................

4. Volcanogenic massive sulfide control area exposed versus number of deposits .......................11

\section{Tables}

1. Name and location of control areas with number of deposits, permissive area, deposit density, deposit age, and map scale used in this study

2. Name and location of control areas with permissive rock units and source of geologic maps used in this study.... $\ldots 4$

3. Names of control area and volcanogenic massive sulfide deposits, location, and tonnage 



\title{
Volcanogenic Massive Sulfide Deposit Density
}

\author{
By Dan L. Mosier, Donald A. Singer, and Vladimir I. Berger
}

\section{Abstract}

A mineral-deposit density model for volcanogenic massive sulfide deposits was constructed from 38 well-explored control areas from around the world. Control areas contain at least one exposed volcanogenic massive sulfide deposit. The control areas used in this study contain 150 kuroko, 14 Urals, and 25 Cyprus massive sulfide subtypes of volcanogenic massive sulfide deposits. For each control area, extent of permissive rock, number of exposed volcanogenic massive sulfide deposits, map scale, deposit age, and deposit density were determined. The frequency distribution of deposit densities in these 38 control areas provides probabilistic estimates of the number of deposits for tracts that are permissive for volcanogenic massive sulfide deposits-90 percent of the control areas have densities of 100 or more deposits per 100,000 square kilometers, 50 percent of the control areas have densities of 700 or more deposits per 100,000 square kilometers, and 10 percent of the control areas have densities of 3,700 or more deposits per 100,000 square kilometers. Both map scale and the size of the control area are shown to be predictors of deposit density. Probabilistic estimates of the number of volcanogenic massive sulfide deposits can be made by conditioning the estimates on sizes of permissive area.

The model constructed for this study provides a powerful tool for estimating the number of undiscovered volcanogenic massive sulfide deposits when conducting resource assessments. The value of these deposit densities is due to the consistency of these models with the grade and tonnage and the descriptive models. Mineral-deposit density models combined with grade and tonnage models allow reasonable estimates of the number, size, and grades of volcanogenic massive sulfide deposits to be made.

\section{Introduction}

Estimating the Earth's undiscovered mineral resources is crucial in considering the future supply of minerals. Quantitative statistical methods can be applied to make unbiased estimates of undiscovered deposits where analogies to wellexplored areas are made (Singer and others, 2001). Estimates of the number of undiscovered deposits can rely on analogies to similar well-explored areas in the same way that grades and tonnages of well-explored deposits serve as analogs of the grades and tonnages of similar undiscovered deposits. These statistical estimates, or base-rates, are prepared from counts of known deposits per unit area in explored regions.

In an early attempt at making quantitative estimates of undiscovered deposits, the number of ore deposits per square kilometer from several explored areas was used with the Poisson distribution to estimate the number of ore deposits existing in a relatively unexplored area (Allais, 1957). Bliss and others (1987) described a method of using mineral-deposit densities by deposit types as a useful tool for mineral resource assessments. These statistical estimates, or base-rates, used counts of known deposits per unit area in explored regions for some deposit types. These deposit types can be used as a guide for number-of-deposits estimates: low-sulfide gold-quartz veins (Bliss and others, 1987, Bliss and Menzie, 1993), four subtypes of volcanogenic manganese deposits (Mosier and Page, 1988), bedded barite deposits (Orris and Bliss, 1989), diamond kimberlite pipes (Bliss, 1992), vein mercury (Root and others, 1992), podiform chromite (Singer, 1994), placer gold, kuroko massive sulfide, porphyry copper, Climax porphyry molybdenum, and wolframite quartz vein deposits (Singer and others, 2001), and three subtypes of porphyry copper deposits (Singer and others, 2005).

Most of these studies provide point or single estimates of the number of deposits per unit area. In some studies, these single estimates of a deposit type might represent high estimates of the number of undiscovered deposits because the studies were restricted to well-documented places with large resources and high densities of deposits. Recent studies (Singer, 1994; Singer and others, 2005) document the variability in densities in porphyry copper and podiform chromite deposit types. Frequencies of deposit densities in well-studied geologically similar regions can be used to estimate frequencies of densities of deposits in assessed regions, just as frequencies of tonnages and grades of well-explored deposits can be used to estimate grades and tonnages of undiscovered deposits. This study presents 38 control areas of deposit densities for volcanogenic massive sulfide deposits from around the world. This large number of deposit densities for volcanogenic massive sulfide deposits allows the variability of depositdensity estimates and the examination of possible effects of deposit tonnage, deposit age, and map scale on these deposit densities to be studied. 


\section{Methodology}

Volcanogenic massive sulfide deposits, also referred to as volcanic-hosted massive sulfide deposits, have been variously grouped into different classes based primarily on geologic setting. Classification of the subtypes is not generally agreed upon in the scientific literature, but this study recognizes two broad subtypes of volcanogenic massive sulfide deposits, designated as kuroko- and Cyprus-type as defined by Cox and Singer (1986). In known world resources, these deposits contain 5 percent of the world's copper, 22 percent of the world's zinc, 10 percent of the world's lead, 2 percent of the world's gold, and 9 percent of the world's silver (Singer, 1995).

In this study, 38 control areas from around the world that contain volcanogenic massive sulfide deposits, and that are considered to be well explored, were selected for mineral-deposit density modeling. There are 31 control areas containing 145 kuroko-type deposits, 1 control area containing a mixture of 5 kuroko-type and 14 Urals-type deposits, and 6 control areas containing 25 Cyprus-type massive sulfide deposits. The kuroko massive sulfide and Cyprus massive sulfide deposit types used in the density model are defined in the descriptive and tonnage-grade models for kuroko (Singer, 1986b; Singer and Mosier, 1986b) and Cyprus (Singer, 1986a; Singer and Mosier, 1986a) massive sulfide deposits. The Urals massive sulfide deposits provisionally used in the density model are based on recent regional studies (Herrington and others, 2005; Prokin and Buslaev, 1999) of the Urals of Russia and Kazakhstan. Descriptive and tonnage-grade models of possible subtypes of massive sulfide deposits are under active study. Using consistent models helps to avoid introduction of biases in assessments.

Kuroko-type massive sulfide deposits typically occur in marine felsic to mafic volcanic and associated sedimentary rocks that formed in or near continental margin arcs and back arcs (Singer, 1986b). The deposits usually are formed by submarine hydrothermal activity during the waning stages of volcanism, and many are associated with local, small rhyoliticto dacitic-intrusive bodies. These deposits commonly have massive lenses of sphalerite, pyrite, chalcopyrite, and locally, galena, gold- and silver-bearing minerals, and other minor sulfides. A footwall stockwork zone of stringers and disseminations of iron- and copper-bearing sulfides accompany some massive sulfide lenses. The median tonnage of 432 deposits in the kuroko massive sulfide model is 1.5 million metric tons, and median grades are 1.3 percent copper, 2.0 percent zinc, 0.16 grams per metric ton gold, and 13 grams per metric ton silver (Singer and Mosier, 1986b).

Urals-type massive sulfide deposits occur in marine mafic and subordinate felsic volcanic rocks formed in spreading back-arc and front-arc rift basins. The deposits are formed by submarine hydrothermal activity during the waning stages of volcanism in local depressions and mostly near small rhyolitic to dacitic subvolcanic bodies. The deposits form massive lenses of pyrite, chalcopyrite, sphalerite, and other minor sulfides. According to preliminary estimates for this study, the median tonnage for 30 Urals-type massive sulfide deposits is 18 million metric tons, and the median grades are 2.0 percent copper and 1.5 percent zinc (Herrington and others, 2005; Prokin and Buslaev, 1999).

Cyprus-type massive sulfide deposits occur in marine mafic volcanic and associated sedimentary rocks that form along oceanic ridges or in spreading back-arc rift basins (Singer, 1986a). The pillow basalts and diabase dikes that host the deposits form the upper part of ophiolite sequences. The deposits form massive lenses of pyrite, chalcopyrite, sphalerite, gold- and silver-bearing minerals, and other minor sulfides. A footwall stockwork zone of stringers and disseminations of sulfides accompany some massive sulfide lenses. Median tonnage for 49 deposits in the Cyprus massive sulfide model is 1.6 million metric tons, and the median copper grade is 1.7 percent (Singer and Mosier, 1986a).

In this study, selection of density-control areas had to meet three criteria:

1. The area had to contain exposed volcanogenic massive sulfide deposits with tonnages and grades consistent with the grade-tonnage models for kuroko- or Cyprustype deposits. Each deposit needed to be separated from other deposits by at least 500 meters of barren rock. Exposure of the deposits had to include the weathered gossan zones, or part of the massive sulfide bodies themselves.

2. Permissive host rocks or hosting units needed to be shown as outcrops on geologic maps with scales no smaller than 1:2,500,000.

3. Surficial areas of permissive host rocks must have been well explored, and all deposits exposed at the surface must be believed to have been found. Although it was not necessary that the control area be completely explored, it was important that the proportion of the number of exposed deposits and areas explored be estimated.

To determine the size of the permissive control areas, the geologic maps were scanned and imported into MapInfo ${ }^{\mathrm{TM}}$ v. 4.0. The geologic contacts were digitized as polygons and the areas were computed in square kilometers.

Deposit densities were computed by dividing the number of exposed deposits by the permissive area for the occurrence of the deposit type. Densities were normalized to 100,000 square kilometers in order to present the data as whole numbers of deposits, rather than as fractions of deposits, and to make the numbers compatible with densities recently published for other deposit types. The control-area data used in this study are presented in table 1 . The permissive rocks in the control areas and source maps are listed in table 2 . The volcanogenic massive sulfide deposits and their sizes are listed in table 3 . 
Table 1. Name and location of control areas with number of deposits, permissive area, deposit density, deposit age, and map scale used in this study.

[n, number; $\mathrm{km}^{2}$, square kilometers; USA, United States of America]

\begin{tabular}{|c|c|c|c|c|c|c|c|}
\hline Control area name and location & Type & $\begin{array}{c}\text { Deposits } \\
\text { (n) }\end{array}$ & $\begin{array}{c}\text { Permissive } \\
\text { area } \\
\left(\mathbf{k m}^{2}\right)\end{array}$ & $\begin{array}{c}\text { Density } \\
\text { (deposits/ } \\
\text { km²) }^{2}\end{array}$ & $\begin{array}{c}\text { Normalized } \\
\text { density } \\
\text { (density x 105) }\end{array}$ & $\begin{array}{l}\text { Age } \\
\text { (Ma) }\end{array}$ & $\begin{array}{l}\text { Map scale } \\
\quad(1: n)\end{array}$ \\
\hline Ammonoosuc, Maine-Connecticutt, USA & kuroko & 3 & 1,136 & 0.0026 & 264 & 450 & 500,000 \\
\hline Ashland, Alabama, USA & kuroko & 1 & 81 & 0.0123 & 1235 & 1,000 & 500,000 \\
\hline Betts Cove, Newfoundland, Canada & Cyprus & 4 & 433 & 0.0092 & 924 & 500 & 250,000 \\
\hline Big Mike, Nevada, USA & Cyprus & 1 & 420 & 0.0024 & 238 & 295 & 250,000 \\
\hline Binghampton, Arizona, USA & kuroko & 1 & 26 & 0.0385 & 3,846 & 1,640 & 62,500 \\
\hline Buchans, New Brunswick, Canada & kuroko & 4 & 1,051 & 0.0038 & 381 & 430 & 250,000 \\
\hline Castine, Maine, USA & kuroko & 3 & 236 & 0.0127 & 1,271 & 400 & 500,000 \\
\hline Chestatee, Georgia, USA & kuroko & 1 & 27 & 0.0370 & 3,704 & 850 & 500,000 \\
\hline Copper Hill, California, USA & kuroko & 4 & 424 & 0.0094 & 943 & 154 & 250,000 \\
\hline Dominican Republic & kuroko & 3 & 338 & 0.0089 & 888 & 120 & 250,000 \\
\hline East Shasta, California, USA & kuroko & 2 & 73 & 0.0274 & 2,740 & 250 & 250,000 \\
\hline $\begin{array}{l}\text { Flin Flon-Snow Lake, Manitoba-Saskatchewan, } \\
\text { Canada }\end{array}$ & kuroko & 15 & 2,656 & 0.0056 & 565 & 1,800 & $1,000,000$ \\
\hline Gopher Ridge, California, USA & kuroko & 8 & 1,343 & 0.0060 & 596 & 154 & 250,000 \\
\hline Hawley-Bernard, Massachusetts-Vermont, USA & kuroko & 1 & 297 & 0.0034 & 337 & 450 & 250,000 \\
\hline Hillabee, Alabama-Georgia, USA & kuroko & 2 & 218 & 0.0092 & 917 & 390 & 500,000 \\
\hline Hokoruku, Japan & kuroko & 8 & 900 & 0.0089 & 889 & 15 & 200,000 \\
\hline Iberian Pyrite Belt, Spain-Portugal & kuroko & 48 & 1,300 & 0.0369 & 3,692 & 350 & 200,000 \\
\hline Jerome, Arizona, USA & kuroko & 1 & 24 & 0.0417 & 4,167 & 1,750 & 24,000 \\
\hline Kunitomi, Japan & kuroko & 5 & 416 & 0.0120 & 1,202 & 15 & 200,000 \\
\hline Kutcho Creek, British Columbia, Canada & kuroko & 1 & 243 & 0.0041 & 412 & 244 & $1,267,200$ \\
\hline Lokken, Norway & Cyprus & 2 & 949 & 0.0021 & 211 & 450 & $1,000,000$ \\
\hline Mount Read, Tasmania, Australia & kuroko & 4 & 825 & 0.0048 & 485 & 502 & 250,000 \\
\hline Myra Falls, British Columbia, Canada & kuroko & 2 & 1,117 & 0.0018 & 179 & 370 & $1,267,200$ \\
\hline New Georgia Group, Georgia, USA & kuroko & 2 & 587 & 0.0034 & 341 & 850 & 500,000 \\
\hline North Haven, Maine, USA & kuroko & 1 & 36 & 0.0278 & 2,778 & 680 & 500,000 \\
\hline Orient, Cuba & kuroko & 2 & 3,390 & 0.0006 & 59 & 53 & 250,000 \\
\hline Pecos, New Mexico, USA & kuroko & 1 & 149 & 0.0067 & 671 & 1,500 & 500,000 \\
\hline Quoddy, Maine, USA & kuroko & 2 & 233 & 0.0086 & 858 & 430 & 500,000 \\
\hline Rudny-Altai, Russia-Kazakhstan-China & kuroko & 8 & 20,539 & 0.0004 & 39 & 390 & $2,500,000$ \\
\hline Smartville, California, USA & Cyprus & 3 & 518 & 0.0058 & 579 & 170 & 250,000 \\
\hline Snake River, Oregon-Idaho, USA & kuroko & 2 & 1,071 & 0.0019 & 187 & 250 & 500,000 \\
\hline Standing Pond, Massachusetts-Vermont, USA & kuroko & 1 & 123 & 0.0081 & 813 & 390 & 250,000 \\
\hline Sunro, British Columbia, Canada & Cyprus & 1 & 480 & 0.0021 & 208 & 40 & $1,267,200$ \\
\hline Troodos, Cyprus & Cyprus & 14 & 1,016 & 0.0138 & 1,378 & 85 & 250,000 \\
\hline Urals, Russia-Kazakhstan & $\begin{array}{l}\text { Urals, } \\
\quad \text { kuroko }\end{array}$ & 19 & 81,615 & 0.0002 & 23 & 400 & $2,500,000$ \\
\hline West Shasta, California, USA & kuroko & 8 & 117 & 0.0684 & 6,838 & 380 & 250,000 \\
\hline Winterville, Maine, USA & kuroko & 1 & 621 & 0.0016 & 161 & 450 & 500,000 \\
\hline Yavapai, Arizona, USA & kuroko & 1 & 89 & 0.0112 & 1,124 & 1,700 & 375,000 \\
\hline
\end{tabular}


Table 2. Name and location of control areas with permissive rock units and source of geologic maps used in this study.

[Fm, Formation; USA, United States of America]

\begin{tabular}{|c|c|c|}
\hline Control area name and location & Permissive rock units & Source \\
\hline $\begin{array}{l}\text { Ammonoosuc, Maine- } \\
\text { Connecticut, USA }\end{array}$ & Ordovician Ammonoosuc Volcanics and Middleton Fm & $\begin{array}{l}\text { Osberg, Hussey, and Boone, 1985; Rodgers, 1985; } \\
\text { Zen and others, 1983; Lyons and others, } 1997\end{array}$ \\
\hline Ashland, Alabama, USA & $\begin{array}{l}\text { Precambrian (Algonkian) Ashland } \\
\text { amphibolite }\end{array}$ & Stone, 1926 \\
\hline $\begin{array}{l}\text { Betts Cove, Newfoundland, } \\
\text { Canada }\end{array}$ & Ordovician Betts Cove and Lush Bight Group & Kean, Dean, and Strong, 1981 \\
\hline Big Mike, Nevada, USA & Pennsylvanian Pumpernickel Fm & $\begin{array}{l}\text { Johnson, 1977; Stewart, McKee, and Stager, 1977; } \\
\text { Willden and Speed, 1974; Willden, } 1964\end{array}$ \\
\hline Binghampton, Arizona, USA & Precambrian Spud Mountain Volcanics (andesite breccia unit) & Anderson and Blacet, 1972a, 1972b \\
\hline $\begin{array}{l}\text { Buchans, New Brunswick, } \\
\text { Canada }\end{array}$ & Ordovician Buchans and Roberts Arm Group & Kean, Dean, and Strong, 1981 \\
\hline Castine, Maine, USA & Silurian-Devonian Castine Fm and equivalent unnamed unit & Osberg, Hussey, and Boone, 1985 \\
\hline Chestatee, Georgia, USA & Upper Precambrian Amphibolite (mm1) & Lawton and others, 1976 \\
\hline Copper Hill, California, USA & Jurassic Copper Hill Volcanics & $\begin{array}{l}\text { Kemp, 1982; Strand and Koenig, 1965; Saucedo and Wagner, 1992; Wagner, } \\
\text { Bortugno, and McJunkin, 1990; Wagner and others, 1981; Strand, } 1967\end{array}$ \\
\hline Dominican Republic & Cretaceous Maimon Fm and Amina Schist & Blesch, 1967 \\
\hline East Shasta, California, USA & Permian Bully Hill Rhyolite & Albers and Robertson, 1961; Fraticelli and others, 1987 \\
\hline $\begin{array}{l}\text { Flin Flon-Snow Lake, Manitoba- } \\
\text { Saskatchewan, Canada }\end{array}$ & Precambrian Amisk Group & $\begin{array}{l}\text { Manitoba Mineral Resources Division, 1980; } \\
\text { Whitaker and Pearson, } 1972\end{array}$ \\
\hline Gopher Ridge, California, USA & Jurassic Gopher Ridge Volcanics and Western Volcanics & $\begin{array}{l}\text { Kemp, 1982; Strand and Koenig, 1965; Saucedo and Wagner, 1992; Wagner, } \\
\text { Bortugno, and McJunkin, 1990; Wagner and others, 1981; Strand, } 1967\end{array}$ \\
\hline $\begin{array}{l}\text { Hawley-Bernard, Massachusetts- } \\
\text { Vermont, USA }\end{array}$ & Ordovician Hawley Fm and Bernard Volcanics & Zen and others, 1983; Doll and others, 1961 \\
\hline Hillabee, Alabama-Georgia, USA & $\begin{array}{l}\text { Post-Carboniferous Hillabee Schist (Alabama), Mafic Schist-Am- } \\
\text { phibolite Schist-Amphibolite (ms2, Georgia) }\end{array}$ & Lawton and others, 1976; Stone, 1926 \\
\hline Hokoruku, Japan & Middle Miocene felsic volcanic rocks & Singer and others, 2001 \\
\hline Iberian Pyrite Belt, Spain-Portugal & $\begin{array}{l}\text { Devonian-Carboniferous Volcano- } \\
\text { Sedimentary Complex }\end{array}$ & $\begin{array}{l}\text { Instituto Geológico y Minero de España, 1970a, 1970b, 1970c; Oliveira } \\
\text { and others, 1984; Oliveira and others, } 1989\end{array}$ \\
\hline Jerome, Arizona, USA & Proterozoic Ash Creek Group & Anderson and Creasey, 1958 \\
\hline Kunitomi, Japan & Middle Miocene Kunitomi Fm and other volcanic units & Ishida, Mimura, and Hiroshima, 1991 \\
\hline $\begin{array}{l}\text { Kutcho Creek, British Columbia, } \\
\text { Canada }\end{array}$ & $\begin{array}{l}\text { Lower-Middle Jurassic Maude Fm sedimentary and volcanic rocks } \\
\text { (map unit 49c, now designated as Permian-Triassic Kutcho Assem- } \\
\text { blage) }\end{array}$ & Little, 1962; Childe and Thompson, 1997 \\
\hline Lokken, Norway & Cambrian-Silurian basic effusive rocks, partly green schists & Holtedahl and Dons, 1953 \\
\hline
\end{tabular}


Table 2. Name and location of control areas with permissive rock units and source of geologic maps used in this study-Continued.

\begin{tabular}{|c|c|c|}
\hline Control area name and location & Permissive rock units & Source \\
\hline Mount Read, Tasmania, Australia & Cambrian Mount Read Volcanics & $\begin{array}{l}\text { Williams and Corbett, 1977; Williams and Turner, 1974; Corbett and } \\
\text { Brown, } 1976\end{array}$ \\
\hline $\begin{array}{l}\text { Myra Falls, British Columbia, } \\
\text { Canada }\end{array}$ & $\begin{array}{l}\text { Permian sedimentary and volcanic rocks (map unit 38, Sicker Group } \\
\text { volcanic-sedimentary rocks) }\end{array}$ & Little, 1962 \\
\hline $\begin{array}{l}\text { New Georgia Group, Georgia, } \\
\text { USA }\end{array}$ & Upper Precambrian Hornblende Gneiss (mm3) & Lawton and others, 1976 \\
\hline North Haven, Maine, USA & Precambrian North Haven Fm & Osberg, Hussey, and Boone, 1985 \\
\hline Orient, Cuba & Paleocene-Eocene Cobre Fm & Instituto de Geológica y Paleontologia, 1988a, 1988b, 1988c, 1988d \\
\hline Pecos, New Mexico, USA & Precambrian metavolcanic rocks & Hunt, 1977 \\
\hline Quoddy, Maine, USA & Silurian Quoddy Fm & Osberg, Hussey, and Boone, 1985 \\
\hline $\begin{array}{l}\text { Rudny-Altai, Russia-Kazakhstan- } \\
\text { China }\end{array}$ & Devonian volcanic and volcanic-sedimentary rocks & $\begin{array}{l}\text { Han and others, 2006; Nalivkin and Sokolov, 1983; Zhefu and Naiyuan, } \\
\text { 1985; Shcherba, } 1983\end{array}$ \\
\hline Smartville, California, USA & Jurassic Smartville Complex (Lower Volcanic Unit) & Saucedo and Wagner, 1992 \\
\hline Snake River, Oregon-Idaho, USA & $\begin{array}{l}\text { Permian-Triassic Hunsaker Creek Fm (Oregon) and Seven Devils } \\
\text { Volcanics (Idaho) }\end{array}$ & $\begin{array}{l}\text { Vallier, 1974; Walker and McLeod, 1991; Gaston and Bennett, 1979; John- } \\
\text { son and Raines, 1996; Bond and others, } 1978\end{array}$ \\
\hline $\begin{array}{l}\text { Standing Pond, Massachusetts- } \\
\text { Vermont, USA }\end{array}$ & Devonian Standing Pond Volcanics & Zen and others, 1983; Doll and others, 1961 \\
\hline Sunro, British Columbia, Canada & $\begin{array}{l}\text { Paleocene to Oligocene sedimentary and volcanic rocks (map unit 58, } \\
\text { now designated as Eocene Metchosin Volcanics }\end{array}$ & Little, 1962; Canada Department of Energy, Mines and Resources, 1980 \\
\hline Troodos, Cyprus & $\begin{array}{l}\text { Upper Cretaceous Troodos Upper Pillow Lava, Lower Pillow Lava, } \\
\text { and Basal Group }\end{array}$ & Geological Survey Department, Cyprus, 1979 \\
\hline Urals, Russia-Kazakhstan & $\begin{array}{l}\text { Silurian to Middle Devonian volcanic and volcanic-sedimentary } \\
\text { rocks }\end{array}$ & $\begin{array}{l}\text { Nalivkin and Sokolov, 1983; Shatov, Seltmann, and Romanovsky, 2001; } \\
\text { Herrington and others, 2005; Prokin and Buslaev, } 1999\end{array}$ \\
\hline West Shasta, California, USA & Devonian Balaklala Rhyolite & Lydon, 1972 \\
\hline Winterville, Maine, USA & Ordovician Winterville Fm & Osberg, Hussey, and Boone, 1985 \\
\hline Yavapai, Arizona, USA & Precambrian Schist (includes Bridle Fm) & Arizona Bureau of Mines, 1953 \\
\hline
\end{tabular}




\section{Delineation of Control Areas}

From data in the descriptive deposit models mentioned previously, kuroko massive sulfide deposits can be expected to be found in marine rhyolitic- to andesitic-volcanic rocks associated with island arcs, and Cyprus massive sulfide deposits can be expected to be found in pillow basalts associated with oceanic spreading ridges. In order to use these models for mineral resource assessments, geologic maps that show the permissive rocks for these deposits must be found. Permissive rocks for volcanogenic massive sulfide deposits are the volcanic or sedimentary rocks that host most ore bodies because the deposits are conformable with the host rocks. These rocks should be delineated as permissive.

The immediate hosting rocks, however, are often lenses or thin layers within a thicker sequence of volcanic and sedimentary rocks and are not differentiated on most geologic map scales. Larger scale maps may show these rock units in greater detail, but larger scale maps are not always available for consistent delineation of control areas, or for delineating permissive tracts in assessments. Smaller scale maps frequently generalize the rock units of relevance into broader rock categories or ages. Grouping these generalized rock sequences results in including rocks that are not considered permissive, thereby increasing the size of the permissive area, which in turn lowers deposit densities.

Other situations may include rock units that conceal permissive rocks, younger intrusive bodies, and water bodies that cover permissive rocks within the polygon of permissive units. Attention was taken to the extent possible to exclude any of these nonpermissive units shown on the map.

The second column in table 2 lists the volcanic rock units or formations that were delineated for the control areas after the data were adjusted for cover or rocks that are not permissive. Special treatment and further explanation of some of the control areas are discussed in more detail below where some effects of assignment of rocks, ages, or affiliations are examined.

The 1962 geologic map of British Columbia, Canada (Little, 1962), that was used for three control areas, exemplifies a common problem encountered when using a small-scale map that contains out-of-date information. In the Kutcho Creek control area, Little's map displays the permissive rocks for the Kutcho Creek massive sulfide deposit as the Lower to Middle Jurassic Maude Formation, consisting of sedimentary and volcanic rocks. Childe and Thompson (1997), however, have reassigned these rocks to the Kutcho Assemblage of Permian to Triassic age. The Maude Formation (table 2) was, therefore, delineated for the permissive area as it closely approximates the extent of the Kutcho Assemblage, but the age of the deposit has been assigned to Triassic rather than Jurassic age (table 1).

In the Sunro area of British Columbia, Little's (1962) Paleocene to Oligocene sedimentary and volcanic rocks were delineated as permissive (table 2). These sedimentary and volcanic rocks have been renamed as the Metchosin Formation
(Canada Department of Energy, Mines and Resources, 1980), and the age of the deposit is listed as Eocene in table 1.

In the Kunitomi district of Hokkaido, Japan, dacite of the Middle Miocene Kunitomi Formation hosts volcanogenic massive sulfide deposits (Ogura, 1974). However, on the geologic map by Ishida, Mimura, and Hiroshima (1991) that was used to delineate the control area, the permissive Kunitomi Formation could not be separated from the nonpermissive Ohiragawa, Shibaribetsugawa, and Furubira formations because all four units were combined as a single unit on the map.

The Rudny-Altai volcanic arc, extending from Kazakhstan and southwestern Russia into northwestern China, is a Devonian bimodal suite of volcanic rocks that hosts many volcanogenic massive sulfide deposits. The control area delineated in the Rudny-Altai was based on Devonian units that included both volcanic and undifferentiated rocks on the geologic maps for Russia (Nalivkin and Sokolov, 1983) and China (Zhefu and others, 1985).

By using the geologic map of Nalivkin and Sokolov (1983) for the Russian Urals, the control area was delineated around Silurian and Lower to Middle Devonian volcanic and undifferentiated rocks that host important volcanogenic massive sulfide deposits. These deposits are classified in the Russian literature as Urals- and (or) Baimak-type (kuroko) deposits that are associated with bimodal volcanic arcs (Prokin and Buslaev, 1999). There were probably multiple volcanic arcs in the Urals that were active during the Silurian to Middle Devonian. These units were combined into a single control area for this study because of the uncertainty of the ages of some of the hosting rock units. The map of the Southern Urals by Shatov and others (2001) was used primarily to verify the locations of the deposits and their hosting units.

In the Snake River area of Oregon and Idaho, the Permian Hunsaker Creek Formation of Vallier (1974), with some modifications to the geologic map of Oregon of Walker and McLeod (1991), was delineated as permissive for volcanogenic massive sulfide deposits. The equivalent formation in Idaho is the Permian-Triassic Seven Devils volcanic rocks (Gaston and Bennett, 1979; Bond and others, 1978). Walker and McLeod (1991) reduced the extent of the Hunsaker Creek Formation in the Wallowa Mountains, Oregon, where some rocks of the Hunsaker Creek Formation west of Homestead were reassigned to the Triassic-Jurassic Hurwal Formation. In the Oxbow along Indian Creek south of Homestead, Oregon, Walker and McLeod (1991) also reassigned the OxbowCuprum shear zone of Vallier (1974) to the Hunsaker Creek Formation.

Deposit densities for the Sierra Nevada, California; Tasmania, Australia; Snow Lake, Canada; and the island of Cyprus are refined here from Singer and others (2001). The largest change is in the Snow Lake area, where the size of the permissive Amisk Group was increased by the addition of the Flin Flon area. This significantly decreased the deposit density for the Flin Flon-Snow Lake area, resulting in a more realistic density value for the Amisk Group (table 1). 
Table 3. Names of control area and volcanogenic massive sulfide deposits, location, and tonnage.

[USA, United States of America]

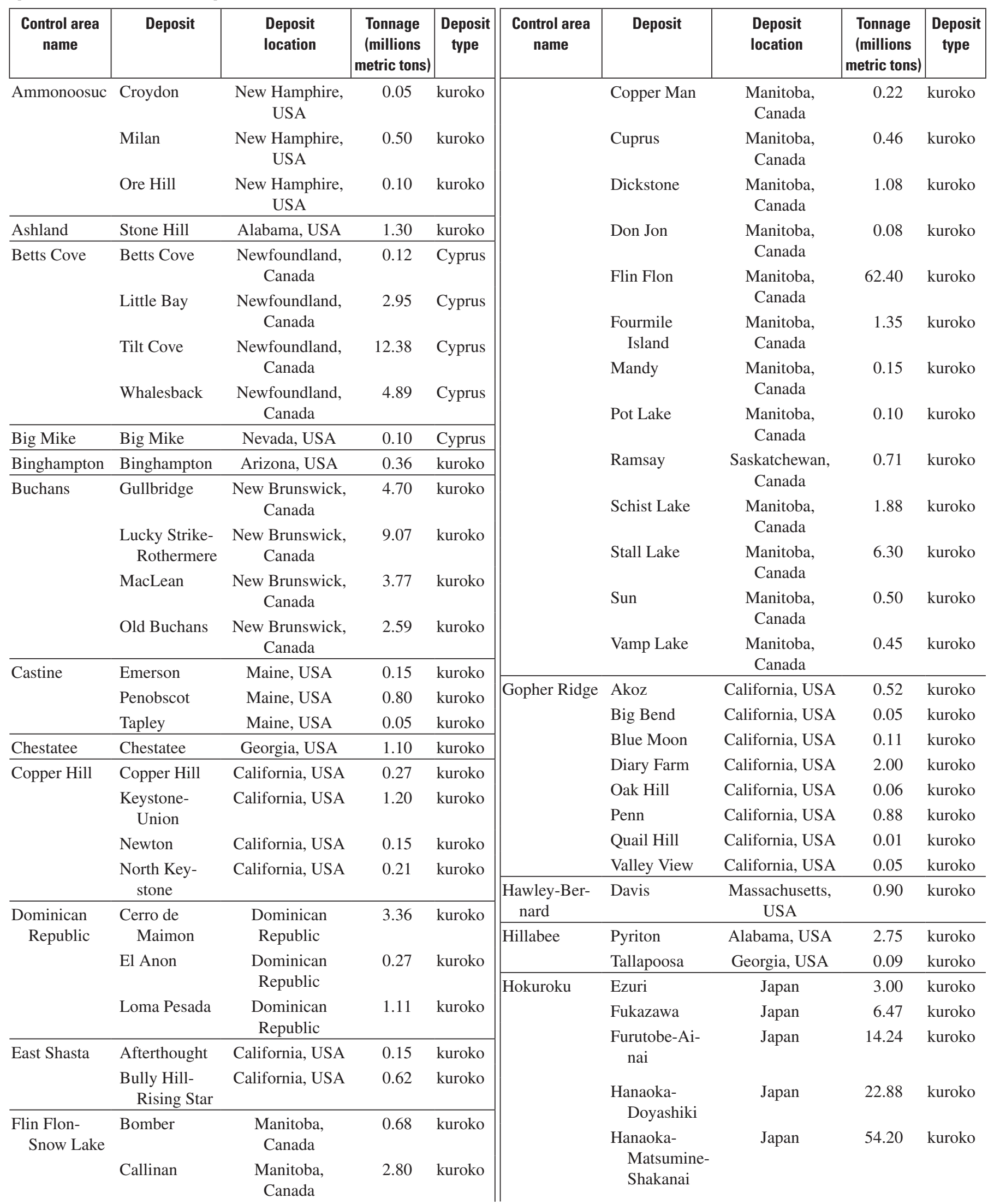


Table 3. Names of control area and volcanogenic massive sulfide deposits, location, and tonnage - Continued.

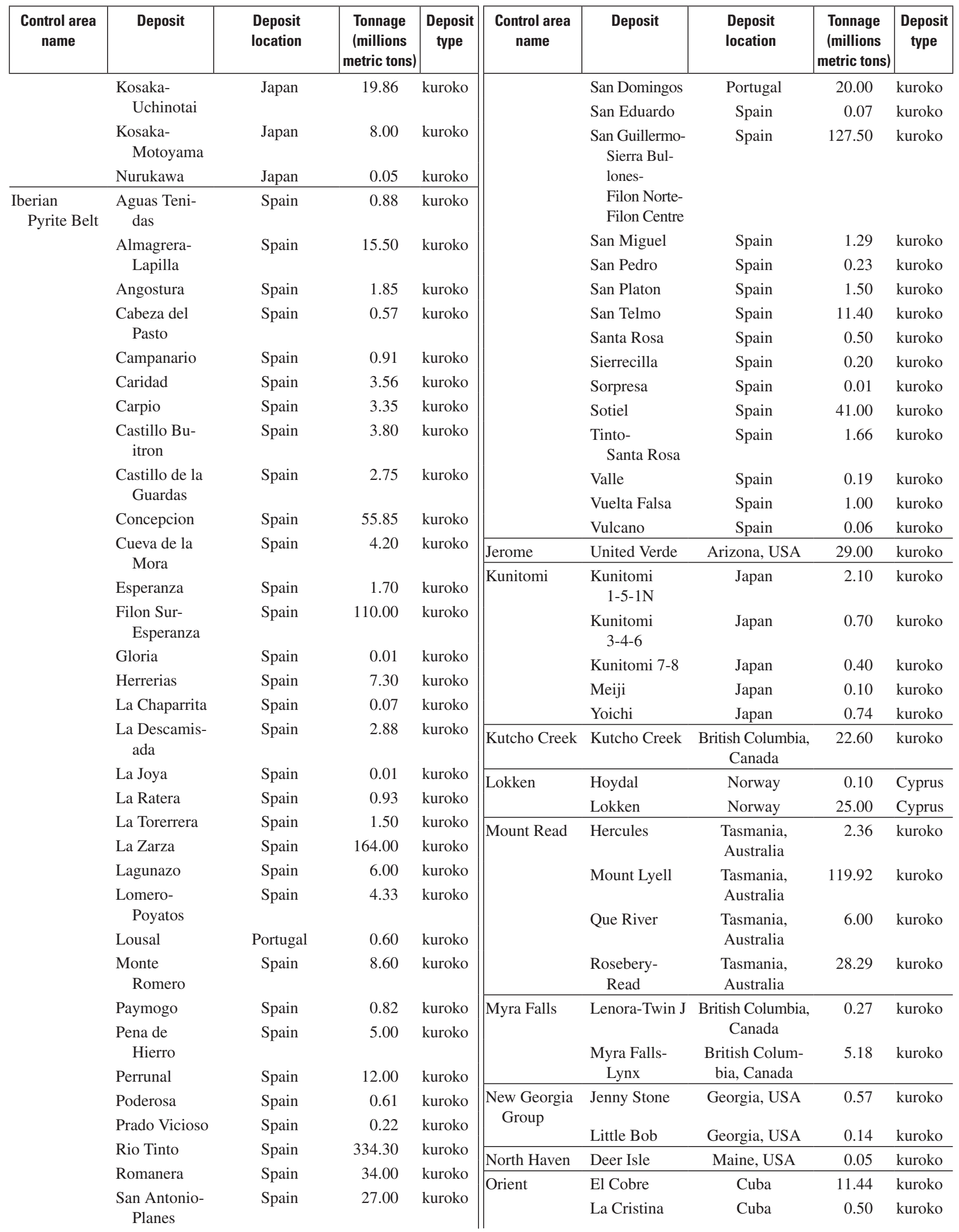


Table 3. Names of control area and volcanogenic massive sulfide deposits, location, and tonnage-Continued.

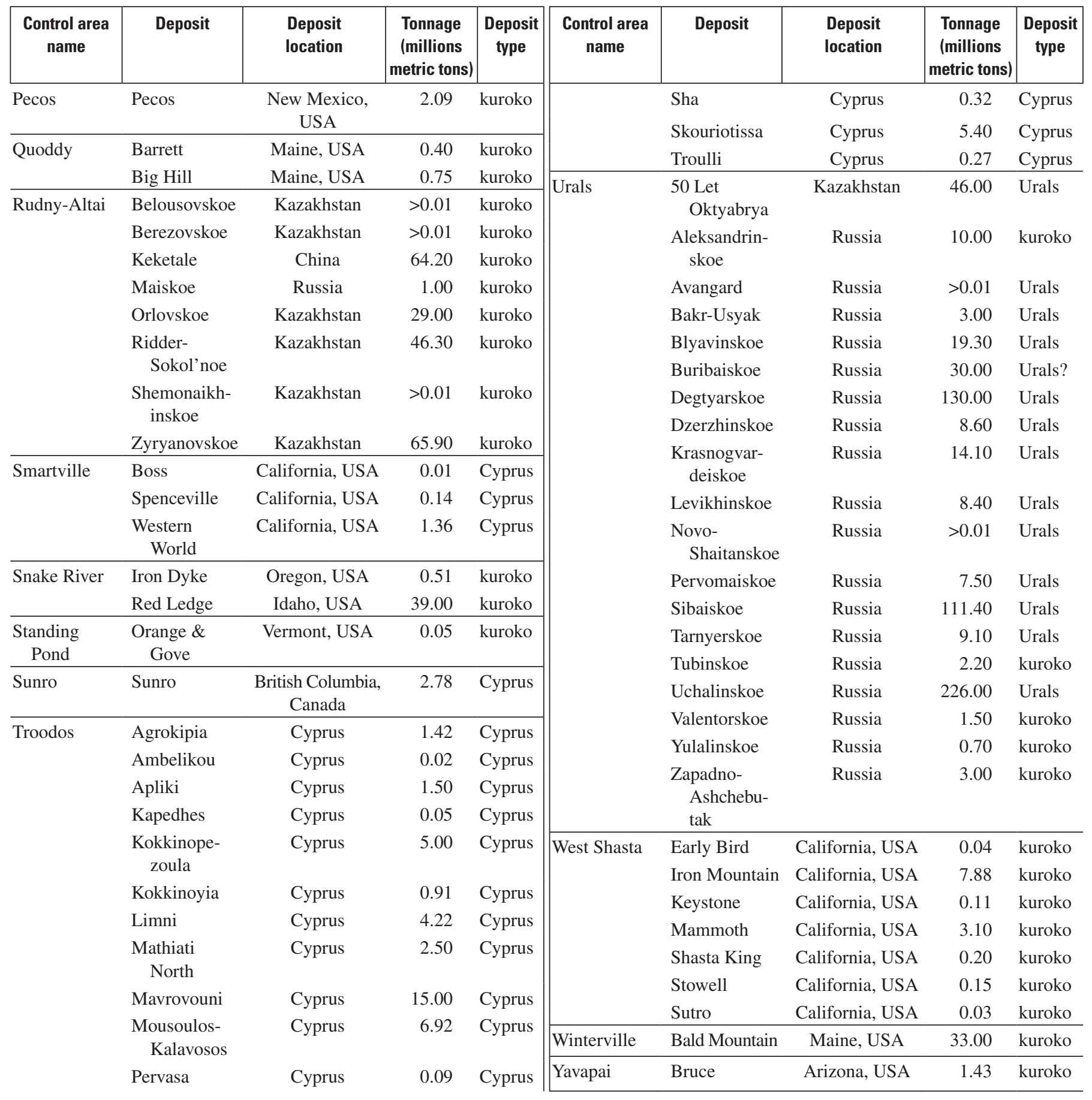


The Hokuroku district, Japan, was added to the data set for this study from data in a previous study by Singer and others (2001). The deposit density for the Hokuroko district is based on eight deposits in the 900-square kilometer basin underlain by Middle Miocene felsic volcanic rocks and overlain mostly by younger sediments. Because the basin has been extensively drilled, with little chance of finding new deposits near the drilling, it was included as part of the control area.

\section{Volcanogenic Massive Sulfide Deposit Densities}

The number of exposed volcanogenic massive sulfide deposits in each control area, adjusted for cover, provides the deposit densities per 100,000 square kilometers listed in table 1 . A comparison of the deposit densities between the kuroko (plus Urals) and Cyprus massive sulfides using the $t$ test demonstrates that there is not a significant difference in their densities, so all subtypes are combined in this study and are hereinafter referred to as volcanogenic massive sulfide deposits.

A histogram of volcanogenic massive sulfide deposit densities (fig. 1) shows a skewed distribution similar to those documented for podiform chromite deposits (Singer, 1994) and porphyry copper deposits (Singer and others, 2005). In such skewed distributions, a few high densities affect the mean density. Although the mean is one measure of central tendency, the median is often a preferable measure in such skewed distributions because it is less affected by a few extreme sample values.

Probabilistic estimates of deposit densities can be made that are not affected by the few high values. A frequency distribution of $\log$ densities provides the probabilistic estimates. In table 1, 90 percent of the control areas have densities of 100 or more volcanogenic massive sulfide deposits per 100,000 square kilometers, 50 percent have densities of 700 or more deposits per 100,000 square kilometers, and 10 percent have densities of 3,700 or more deposits per 100,000 square kilometers. However, there may be factors that allow refinement of these estimates as discussed below.

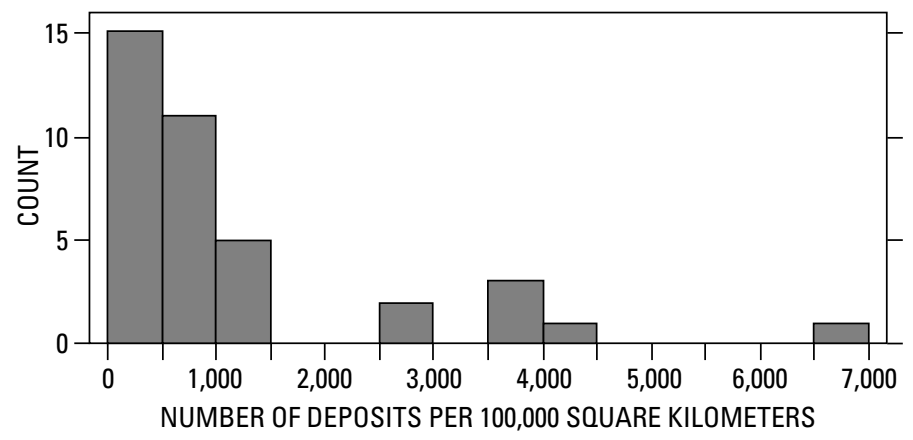

Figure 1. Histogram of volcanogenic massive sulfide deposit densities per 100,000 square kilometers for 38 control areas used in this study.

\section{Erosion and Densities}

It is reasonable to assume that erosion would affect sizes and densities of volcanogenic massive sulfide deposits. If exposure to erosion over time removed deposits, there should be a lower density of deposits in older control areas. If parts of deposits were removed by erosion or tectonics over time, there also should be smaller deposits in older control areas. Deposit densities of volcanogenic massive sulfide deposits were compared to deposit ages to determine if they are related. Deposit densities, however, are not significantly correlated with deposit age ( $r=0.17, n=38)$. This lack of correlation is also supported by the observations in this study that indicate younger deposits are not larger in tonnage than older deposits $(r=-0.006, n=189)$. Thus, erosion over time has no measurable effect on the size or deposit densities of volcanogenic massive sulfide deposits. Similar observations were made with porphyry copper deposits (Singer and others, 2005). Thus, we reject the hypothesis that deposit densities decrease through time. Effects of erosion cannot be demonstrated by diminished sizes of volcanogenic massive sulfide deposits or by lower deposit densities through time.

\section{Map Scales and Densities}

The scale of a geologic map may affect the extent of the permissive rocks. As already mentioned, small-scale maps tend to generalize rock units by combining permissive rocks with nonpermissive rocks, that is, combining felsic volcanic rocks with mafic volcanic rocks. Some small-scale maps may display rocks by geologic age rather than by rock type. For example, the geologic map of the Urals of Russia used in this study (Nalivkin and Sokolov, 1983) combines the volcanic and sedimentary rocks into undifferentiated Silurian or Devonian units. Furthermore, because of the uncertainty of the rock ages around some of the volcanogenic massive sulfide deposits, it was sometimes necessary to combine two age units into a single permissive area. Thus the delineation of the Urals by using a map scale of $1: 2,500,000$ probably results in overestimation of the permissive area, which is expected when using small-scale geologic maps and is likely to result in a smaller mineral-deposit density value. In resource assessments, small-scale maps are commonly the only geologic maps available, therefore, lower mineral-deposit density estimates can be expected.

Deposit density is inversely correlated with map scale (significant at one percent level, $r=-0.63, n=38$; fig. 2). Map scales used in this study range from 1:24,000 to 1:2,500,000. Control areas based on small-scale maps typically contain rocks that are not permissive for volcanogenic massive sulfide deposits, which results in lower deposit densities. Larger scale, more detailed maps are more likely to have excluded areas of nonpermissive rocks resulting in higher deposit densities. Although it might be possible to develop mineral deposit densities from larger scale maps that have more detailed mapping, in applying densities in assessments, such detailed maps are frequently not available. This inverse relationship is inherent 


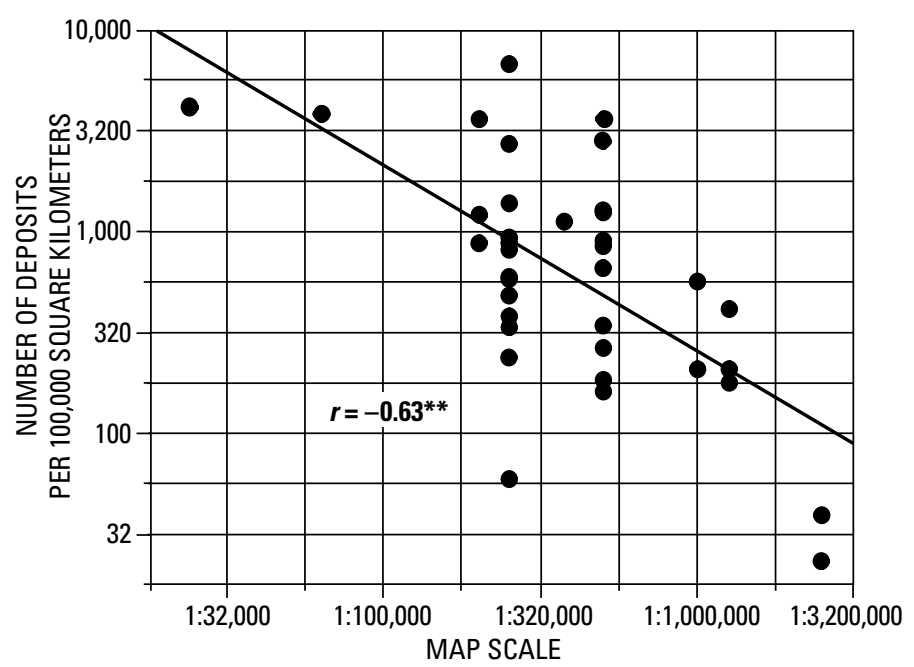

Figure 2. Relationship of map scale and volcanogenic massive sulfide deposits densities per 100,000 square kilometers $\left({ }^{* *}\right.$ significant at one-percent level of confidence). Dots represent control areas scattered about the regression line.

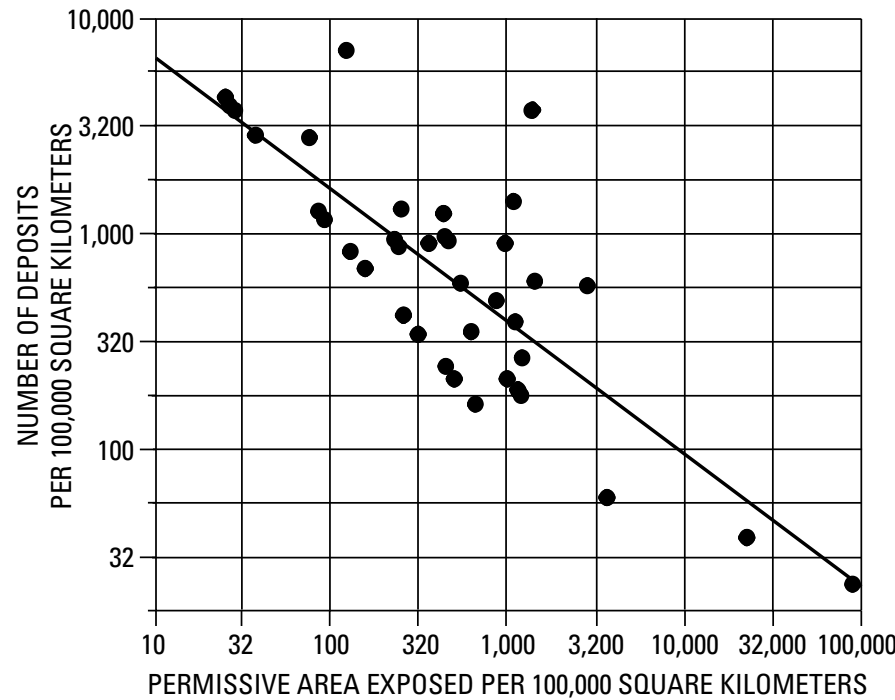

Figure 3. Volcanogenic massive sulfide deposits control area exposed versus density of deposits. Dots represent control areas scattered about the regression line.

in the rules used to define control areas, which depend on map scale and information content.

\section{Area and Densities}

Control areas in this study range in size from 24 to 82,000 square kilometers and contain at least one exposed volcanogenic massive sulfide deposit. Typically, control-area sizes represent the extent of exposed rocks permissive for volcanogenic massive sulfide deposits. As noted above, control areas with larger sizes may contain some nonpermissive rock units because of the way the units are generalized on the map, resulting in lower deposit-density values. Control areas with smaller sizes are more likely to contain only rock units permissive for volcanogenic massive sulfide deposits, thus resulting in higher deposit densities. Mineral deposit densities are inversely related to the size of the permissive control areas (fig. 3 ; significant at the one percent level, $r=-0.8, n=38$ ). This relationship suggests the size of the permissive area can be used directly to estimate the number of deposits similar to the way podiform chromite deposits (Singer, 1994) and porphyry copper deposits were evaluated (Singer and others, 2005).

Estimates of the number of volcanogenic massive sulfide deposits can be made from figure 4 by using the permissive area on the $\mathrm{X}$-axis projected to the 90 -percent confidence limit for a lower estimate of the number of deposits, to the regression line for the 50-percent estimate, and to the 10-percent confidence limit for an upper estimate. The linear regression line and confidence limits to estimate the number of deposits for individual permissive areas are based on 38 control areas. For more precise estimates than can be shown in the log-log plot, the following two equations are provided:

$$
\begin{gathered}
R_{50}=-0.5846+0.3846 \log _{10}(\text { area }) \\
L_{90}, U_{10}=\left(R_{50} \pm t s_{y \mid x} \sqrt{ }(1+(1 / n)+\right. \\
\left.\left(\log _{10}(\text { area })-2.637\right)^{2} /(n-1) s_{x}^{2}\right)
\end{gathered}
$$

Where, area is the area that is permissive in square kilometers, the mean area is 2.637, $t$ (Student's $t$ at the 10-percent level with 36 degrees of freedom, $t_{10,36 \mathrm{df}}$ ) is $1.688, s_{y \mid x}$ (standard

PERMISSIVE AREA PER 100 SQUARE KILOMETERS

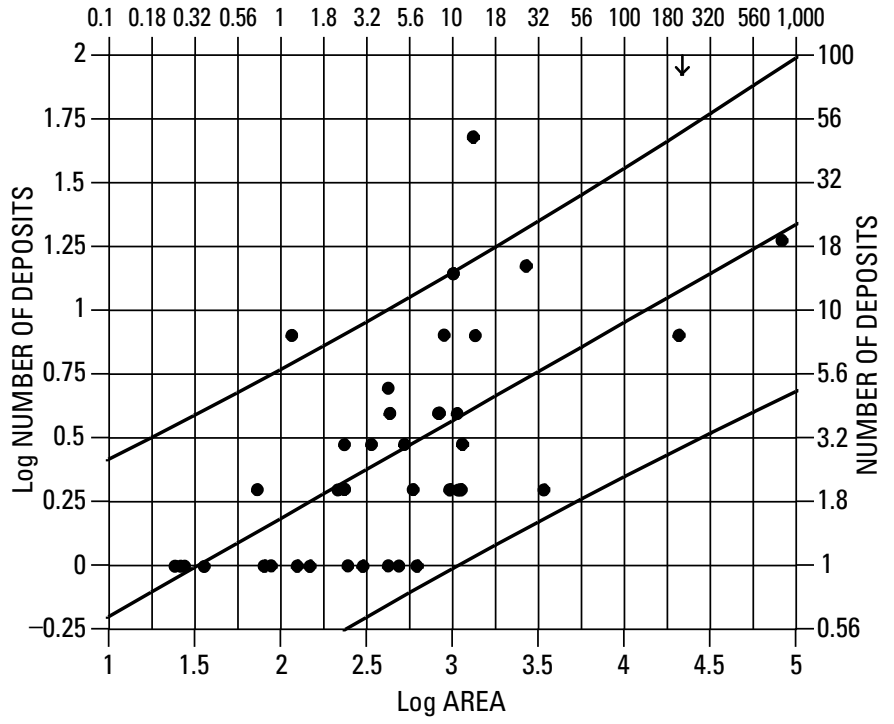

Figure 4. Volcanogenic massive sulfide control area exposed versus number of deposits with 90-percent (lower line) and 10-percent (upper line) confidence limits for number of deposits. Dots represent control areas scattered about the regression line (middle line). Arrow at 22,900 square kilometers on the permissive-area axis refers to the sample given in the text where equation 1 is discussed. 
deviation of number of deposits given area) is $0.3379, n=38$, $s_{x}^{2}$ (variance of area) is 0.5258 , and the $R_{50}, L_{90}$, and $U_{10}$ estimates are used as exponents to the power of 10 . For example, if the permissive area were 22,900 square kilometers, then the 50 th percentile estimate would be 12 deposits (that is, $10^{1.092}$ or $\left.10^{(-0.5846+0.3846 \log 10(22,900))}\right)$. The 90 th percentile estimate would be 3 deposits (that is, $10^{\left(1.092-1.688 \cdot 0.3379 \sqrt{ }\left(1+(1 / 38)+(4.360-2.637)^{\wedge} 2\right.\right.}$ $137 \cdot 0.5258)$, and the 10 th percentile estimate would be 48 deposits - these estimates can be approximated from figure 4 . These estimates represent the total number of volcanogenic massive sulfide deposits in a permissive tract of 22,900 square kilometers, and any discovered deposits would need to be subtracted to estimate the number of undiscovered deposits.

\section{Summary and Conclusions}

A mineral deposit-density model provides frequencies of deposits per square kilometer in well-explored permissive terranes. Frequencies of deposit densities for a deposit type allow reasonable probabilistic estimates of undiscovered deposits to be made in geologically similar, relatively unexplored terranes. Such models, developed for particular deposit types, can be used to estimate the number of undiscovered deposits of that type in resource assessments.

Because this model is derived from well-explored volcanogenic massive sulfide deposits that occur at the surface, it should be applied to estimates of undiscovered deposits at the surface, not at depth, in similar geologic environments. The effect of this limitation is not known with certainty. In some locations there appear to be multiple horizons containing volcanogenic massive sulfide deposits, for example, Mount Read Volcanics, Tasmania (Large and others, 2001). Where multiple horizons are suspected in an assessment the best policy would seem to be to apply the density models to each horizon.

The volcanogenic massive sulfide deposit-density model was constructed from 38 areas from around the world that are known to contain at least one deposit that is consistent with the descriptive models and the grade and tonnage models for kuroko or Cyprus massive sulfide deposits. Deposits selected in these control areas are exposed at the surface, and the areas of permissive rock exposed at the surface are well explored, such that there is little or no chance of finding additional deposits at the surface. The permissive area should represent only the hosting units, and all nonhosting units or cover material within the permissive areas should be excluded to the extent possible. The level of geologic mapping and map scale affect the final size of the permissive area resulting in lower deposit densities for areas mapped at smaller scales and for larger areas that may contain nonpermissive rocks that cannot be differentiated. Thus, it is important to use the most detailed geologic map available (large-scale map) when delineating permissive areas in order to improve the precision of number-of-deposit estimates.

Deposit densities are computed by dividing the number of exposed deposits in the control area by the area of permissive rock per square kilometer. Density values multiplied by the arbitrary unit area, 100,000 square kilometers, present the densities as integers rather than as decimals. Kuroko and Cyprus massive sulfide deposit types show no difference in mineral deposit densities, so they have been combined in this study.

The data for this study indicates that 90 percent of the control areas have densities of 100 or more deposits per 100,000 square kilometers, 50 percent of the control areas have densities of 700 or more deposits per 100,000 square kilometers, and 10 percent of the control areas have densities of 3,700 or more deposits per 100,000 square kilometers. A plot of the log number of deposits and the log areas for the 38 control areas produces a regression line and confidence bands that can be used to estimate the number of deposits at the 50th, 10th, and 90th probability levels, given the area of permissive rock in a mineral resource assessment.

This study provides a powerful tool for estimating the number of undiscovered volcanogenic massive sulfide deposits in resource assessments. The value of these densities derives in part from the consistency of these models with the grade and tonnage and the descriptive models. Combined with grade and tonnage models, reasonable estimates of the number, tonnage, and grades of volcanogenic massive sulfide deposits can be made.

\section{Acknowledgments}

We thank W. David Menzie, III, James Bliss, and Thomas Frost of the USGS for helpful comments on this manuscript. We thank Anna Tellez, Susie Bravos, Tammy Huang, Jon DeBord, Brenda Graff, and Jean Shea of the USGS library staff for helping us find geologic maps and reports from around the world. We thank Tracey Suzuki and James W. Hendley for editing the manuscript.

\section{References Cited}

Albers, J.P., and Robertson, J.F., 1961, Geology and ore deposits of East Shasta copper-zinc district, Shasta County, California: U.S. Geological Survey Professional Paper 338, $107 \mathrm{p}$.

Allais, M., 1957, Method of appraising economic prospects of mining exploration over large territories-Algerian Sahara case study: Management Science, v. 3, p. 285-345.

Anderson, C.A., and Blacet, P.M., 1972a, Geologic map of the Mayer Quadrangle, Yavapai County, Arizona: U.S. Geological Survey Geological Quadrangle Map GQ-996, scale 1:62,500.

Anderson, C.A., and Blacet, P.M., 1972b, Geologic map of the Mingus Mountain Quadrangle, Yavapai County, Arizona: U.S. Geological Survey Geological Quadrangle Map GQ715 , scale 1:62,500. 
Anderson, C.A., and Creasey, S.C., 1958, Geology and ore deposits of the Jerome area, Yavapai County, Arizona: U.S. Geological Survey Professional Paper 308, 185 p.

Arizona Bureau of Mines, 1953, Geologic map of Yavapai County, Arizona: Tucson, University of Arizona, scale 1:375,000.

Blesch, R.R., 1967, Mapa geológico preliminary con información del agua subterranean y datos mineralógicos República Dominicana: Organización de los Estados Americanos, scale 1:250,000.

Bliss, J.D., 1992, Grade-tonnage and other models for diamond kimberlite pipes: Nonrenewable Resources, v. 1, no. 3, p. 214-230.

Bliss, J.D., and Menzie, W.D., 1993, Spatial mineral-deposit models and the prediction of undiscovered mineral deposits, in Kirkham, R.V., Sinclair, W.D., Thorpe, R.I., and Duke, J.M., eds., Mineral deposit modeling: Geological Association Canada Special Paper 40, p. 693-706.

Bliss, J.D., Menzie, W.D., Orris, G.J., and Page, N.J, 1987, Mineral deposit density —A useful tool for mineral-resource assessment [abs.], in Sachs, J.S., ed., U.S. Geological Survey research of mineral resources-1987 program and abstracts: U.S. Geological Survey Circular 995, p. 6.

Bond, J.D., Kauffman, J.D., Miller, D.A., and Venkatakrishnan, Ramesh, 1978, Geologic map of Idaho: Idaho Bureau of Mines and Geology Map GM-1, scale 1:500,000.

Canada Department of Energy, Mines and Resources, 1980, Canadian mineral deposits not being mined in 1980: Mineral Policy Sector Internal Report MRI 80/7, 294 p.

Childe, F.C., and Thompson, J.F.H., 1997, Geological setting, $\mathrm{U}-\mathrm{Pb}$ geochronology, and radiogenic isotopic characteristics of the Permo-Triassic Kutcho Assemblage, north-central British Columbia: Canadian Journal of Earth Science, v. 34, p. 1310-1324.

Corbett, K.D., and Brown, A.V., 1976, Queenstown: Tasmania Department of Mines Geological Atlas 1:250,000 Series Sheet No. SK-55/5, scale 1:250,000.

Cox, D.P., and Singer, D.A., eds., 1986, Mineral deposit models: U.S. Geological Survey Bulletin 1693, 379 p.

Doll, C.G., Cady, W.M., Thompson, J.B., Jr., and Billings, M.P., 1961, Centennial geologic map of Vermont: Vermont Geological Survey, scale 1:250,000.

Fraticelli, L.A., Albers, J.P., Irwin, W.P., and Blake, M.C., 1987, Geologic map of the Redding 1x2 degree quadrangle, Shasta, Tehema, Humboldt, and Trinity counties, California: U.S. Geological Survey Open-File Report 87-257, scale 1:250,000.
Gaston, M.P., and Bennett, E.H., 1979, Geologic map of the Grangeville Quadrangle, Idaho: Idaho Bureau of Mines and Geology Map GM-9, scale 1:250,000.

Geological Survey Department, Cyprus, 1979, Geological map of Cyprus: scale 1:250,000.

Han, C., Xiao, W., Zhao, G., Mao, J., Li, S, Yan, Z., and Mao, Q., 2006, Major types, characteristics and geodynamic mechanism of Upper Paleozoic copper deposits in northern Xinjiang, northwestern China: Ore Geology Reviews, v. 28, no. 3, p. 308-328.

Herrington, R.J., Zaykov, V.V., Maslennikov, V.V., Brown, D., and Puchkov V.N., 2005, Mineral deposits of the Urals and links to geodynamic evolution, in Hedenquist, J.W., Thompson, J.H.F., Goldfarb, R.J., and Richards, J.P., eds., Economic Geology 100th anniversary volume: Society of Economic Geologists, Littleton, Colorado, p. 1069-1095, CD Supplemented Appendices.

Holtedahl, O., and Dons, J.A., 1953, Berggrunnskart over Norge: Norges Geologiske Undersokelse, scale 1:1,000,000.

Hunt, C.B., 1977, Surficial geology of northeast New Mexico: New Mexico Bureau of Mines and Mineral Resources Geologic Map 40, scale 1:500,000.

Instituto de Geologia y Paleontologia, 1988a, Mapa geológico de Cuba: Academia de Ciencias de Cuba, sheet 30, scale $1: 250,000$.

Instituto de Geologia y Paleontologia, 1988b, Mapa geológico de Cuba: Academia de Ciencias de Cuba, sheet 31, scale $1: 250,000$.

Instituto de Geologia y Paleontologia, 1988c, Mapa geológico de Cuba: Academia de Ciencias de Cuba, sheet 38, scale $1: 250,000$.

Instituto de Geologia y Paleontologia, 1988d, Mapa geológico de Cuba: Academia de Ciencias de Cuba, sheet 39, scale $1: 250,000$.

Instituto Geológico y Minero de España, 1970a, Mapa geológico Cordoba: sheet 76, scale 1:200,000.

Instituto Geológico y Minero de España, 1970b, Mapa geológico Puebla de Guzman: sheet 74, scale 1:200,000.

Instituto Geológico y Minero de España, 1970c, Mapa geológico Sevilla: sheet 75, scale 1:200,000.

Ishida, Masao, Mimura, Koji, and Hiroshima, Toshio, 1991, Iwanai: Geological Survey of Japan Geological Map NK54-19-20, scale 1:200,000.

Johnson, B.R., and Raines, G.L., 1996, Digital representation of the Idaho state geologic map; a contribution to the Interior Columbia River basin ecosystem management project: U.S. Geological Survey Open-File Report 95-0690 [Last accessed March 19, 2007, at http://pubs.usgs.gov/of/1995/of95-690/]. 
Johnson, M.G., 1977, Geology and mineral deposits of Pershing County, Nevada: Nevada Bureau of Mines and Geology Bulletin 89, 115 p.

Kean, B.F., Dean, P.L., and Strong, D.F., 1981, Regional geology of the Central Volcanic Belt of Newfoundland, in Swanson, E.A., Strong, D.F., and Thurlow, J.G., eds., The Buchans orebodies-Fifty years of geology and mining: The Geological Association of Canada Special Paper no. 22, p. $65-78$.

Kemp, W.R., 1982, Petrochemical affiliations of volcanogenic massive sulfide deposits of the Foothill $\mathrm{Cu}-\mathrm{Zn}$ belt, Sierra Nevada, California: Reno, University of Nevada, Ph.D. dissertation, $458 \mathrm{p}$.

Large, R.R., McPhie, Jocelyn, Gemmell, J.B., Hermann, Walter, and Davidson G.J., 2001, The spectrum of ore deposit types, volcanic environments, alteration halos, and related exploration vectors in submarine volcanic successions-Some examples from Australia: Economic Geology, v. 96, no. 5, p. 913-938.

Lawton, D.E., and others, 1976, Geologic map of Georgia: Georgia Geological Survey, scale 1:500,000.

Little, H.W., 1962, Geological map of British Columbia: Geological Survey of Canada Department of Mines and Technical Surveys Map 932A, 2nd edition, scale 1:1,267,200.

Lydon, P.A., 1972, Geologic map of Shasta County, California: California Division of Mines and Geology County Report 6, scale 1:250,000.

Lyons, J.B., Bothner, W.A., Moench, R.H., and Thompson, J.B., Jr., 1997, Bedrock geologic map of New Hampshire: U.S. Geological Survey, scale 1:250,000.

Manitoba Mineral Resources Division, 1980, Mineral map of Manitoba: Map 80-1, scale 1:1,000,000.

Mosier, D.L., and Page, N.J, 1988, Descriptive and grade-tonnage models of volcanogenic manganese deposits in ocean environments-A modification: U.S. Geological Survey Bulletin 1811, 28 p.

Nalivkin, D.V., and Sokolov, R.I., eds., 1983, Geological map of the USSR and adjoining water-covered areas: Ministry of Geology of the USSR, All-Union Geological Research Institute, 16 sheets, scale 1:2,500,000.

Ogura, N., 1974, Geologic structure, igneous activity and mineralization of the Kunitomi mine area, Hokkaido, in Ishihara, Shunso, Kanehira, Keiichiro, Sasaki, Akira, Sato, Takeo, and Shimazaki, Yoshihiko, eds., Geology of kuroko deposits: Society of Mining Geologists of Japan, Mining Geology Special Issue 6, p. 29-38.

Oliveira, J.T., and others, 1984, Carta geológica de Portugal: Lisboa, Servicos Geológiços de Portugal Folha 7, scale $1: 200,000$.
Oliveira, J.T., and others, 1989, Carta geológica de Portugal: Lisboa, Servicos Geológiços de Portugal Folha 8, scale $1: 200,000$.

Orris, G.J., and Bliss, J.D., 1989, Industrial-rock and mineral-resource-occurrence models, in Tooker, E.W., ed., Arizona's industrial rock and mineral resources-Workshop proceedings: U.S. Geological Survey Bulletin 1905, p. 39-44.

Osburg, P.H., Hussey, A.M., II, and Boone, Gary, 1985, Bedrock geologic map of Maine: Maine Geological Survey, scale 1:500,000.

Prokin, V.A., and Buslaev, F.P., 1999, Massive copper-zinc sulphide deposits in the Urals: Ore Geology Reviews, v. 14, p. 1-69.

Rodgers, John, 1985, Bedrock geological map of Connecticut: Connecticut Geological and Natural History Survey and U.S. Geological Survey, 2 sheets, scale 1:125,000.

Root, D.H., Menzie, W.D., and Scott, W.A., 1992, Computer Monte Carlo simulation in quantitative resource estimation: Nonrenewable Resources, v. 1, no. 2, p. 125-138.

Saucedo, G.J. and Wagner, D.L., 1992, Geologic map of the Chico Quadrangle: California Division of Mines and Geology, Regional Geologic Map Series Map No. 7A, scale $1: 250,000$.

Shatov, V., Seltmann, R., and Romanovsky, G., 2001, Gold mineralization map of the southern Urals: London/ St.Petersburg: Natural History Museum London, NHM, IAGOD, scale 1:1,000,000.

Shcherba, G.N., 1983, Polymetallic massive sulfide deposits of Rudny Altai, in Ivanov, S.N., ed., Massive sulfide deposits of the USSR: Moscow, Nauka Publishing House, p. 87-148 (in Russian).

Singer, D.A., 1986a, Descriptive model of Cyprus massive sulfide, in Cox, D.P., and Singer, D.A., eds., Mineral deposit models: U.S. Geological Survey Bulletin 1693, p. 131.

Singer, D.A., 1986b, Descriptive model of kuroko massive sulfide, in Cox, D.P., and Singer, D.A., eds., Mineral deposit models: U.S. Geological Survey Bulletin 1693, p. 189-190.

Singer, D.A., 1994, Conditional estimates of the number of podiform chromite deposits: Nonrenewable Resources, v. 3, no. 3, p. 200-204.

Singer, D.A., 1995, World-class base and precious metal deposits-A quantitative analysis: Economic Geology, v. 90 , no. 1 , p. $88-104$.

Singer, D.A., Berger, V.I., Menzie, W.D., and Berger, B.R., 2005, Porphyry copper deposit density: Economic Geology, v. 100 , no. 3, p. 491-514. 
Singer, D.A., Menzie, W.D., Sutphin, David, Mosier, D.L., and Bliss, J.D., 2001, Mineral deposit density-An update, in Schulz, K.J., ed., Contributions to global mineral resource assessment research: U.S. Geological Survey Professional Paper 1640-A, p. A1-A13 [last accessed March 19, 2007, at http://pubs.usgs.gov/prof/p1640a/].

Singer, D.A., and Mosier, D.L., 1986a, Grade and tonnage model of Cyprus massive sulfide, in Cox, D.P., and Singer, D.A., eds., Mineral deposit models: U.S. Geological Survey Bulletin 1693, p. 131-135.

Singer, D.A., and Mosier, D.L., 1986b, Grade and tonnage model of kuroko massive sulfide, in Cox, D.P., and Singer, D.A., eds., Mineral deposit models: U.S. Geological Survey Bulletin 1693, p. 190-197.

Stewart, J.H., McKee, E.H., and Stager, H.K., 1977, Geology and mineral deposits of Lander County, Nevada: Nevada Bureau of Mines and Geology Bulletin 88, 106 p.

Stone, G.W., ed., 1926, Geologic map of Alabama: Alabama Geological Survey and U.S. Geological Survey, scale 1:500,000.

Strand, R.G., 1967, Geologic map of California-Mariposa sheet: California Division of Mines and Geology, scale $1: 250,000$.

Strand, R.G., and Koenig, J.B., 1965, Geologic map of California-Sacramento sheet: California Division of Mines and Geology, scale 1:250000.

Vallier, T.L., 1974, A preliminary report on the geology of part of the Snake River Canyon, Oregon and Idaho: Oregon Department of Geology and Mineral Industries Geological Map Series GMS-6, scale 1:125,000.

Wagner, D.L., Bortugno, E.J., and McJunkin, R.D., 1990, Geologic map of the San Francisco-San Jose Quadrangle: California Division of Mines and Geology, Regional Geologic Map Series Map No. 5A, scale 1:250,000.
Wagner, D.L., Jennings, C.W., Dedrossian, T.L., and Bortugno, E.J., 1981, Geologic map of the Sacramento Quadrangle: California Division of Mines and Geology, Regional Geological Map Series Map No. 1A, scale 1:250,000.

Walker, G.W., and McLeod, N.S., 1991, Geologic map of Oregon: U.S. Geological Survey, scale 1:500,000.

Whitaker, S.H., and Pearson, D.E., 1972, Geological map of Saskatchewan: Saskatchewan Department of Mineral Resources and Saskatchewan Research Council, scale $1: 1,267,200$.

Willden, C.R., 1964, Geology and mineral deposits of Humboldt County, Nevada: Nevada Bureau of Mines and Geology Bulletin 59, 154 p.

Willden, R., and Speed, R.C., 1974, Geology and mineral deposits of Churchill County, Nevada: Nevada Bureau of Mines and Geology Bulletin 83, 95 p.

Williams, P.R., and Corbett, E.B., 1977, Port Davey: Tasmania Department of Mines Geological Atlas 1:250,000 Series Sheet No. SK-55/7, scale 1:250,000.

Williams, E., and Turner, N.J., 1974, Burnie: Tasmania Department of Mines Geological Atlas 1:250,000 Series Sheet No. SK-55/3, scale 1:250,000.

Zen, E-an, Goldsmith, Richard, Ratcliffe, N.M., Robinson, Peter, and Stanley, R.S., 1983, Bedrock geologic map of Massachusetts: U.S. Geological Survey, 3 sheets, scale $1: 250,000$.

Zhefu, Chen, and Naiyuan, Wu, eds., 1985, Geological map of Xinjiang Uygur autonomous region China: Geological Publishing House, 4 sheets, scale 1:2,000,000. 